\title{
Familiar Perversions
}





\title{
Familiar Perversions
}

The Racial, Sexual, and Economic Politics of LGBT Families

\author{
LIZ MONTEGARY
}

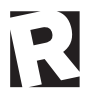

Rutgers University Press

New Brunswick, Camden, and Newark, New Jersey, and London 
Library of Congress Cataloging-in-Publication Data

Names: Montegary, Liz, author.

Title: Familiar perversions : the racial, sexual, and economic politics of LGBT families /

Liz Montegary.

Description: New Brunswick : Rutgers University Press, [2018] | Includes bibliographical references and index.

Identifiers: LCCN 2017055196 | ISBN 9780813591360 (cloth : alk. paper) |

ISBN 9780813591353 (pbk. : alk. paper)

Subjects: LCSH: Gay parents-United States. | Sexual minorities' families-United

States. | Families-United States. | Family policy-United States. | Equality-United States. |

Gay rights-United States.

Classification: LCC HQ75.28.U6 M66 2018 | DDC 306.874086/64-dc23

LC record available at https://lccn.loc.gov/2017055196

A British Cataloging-in-Publication record for this book is available from the British Library.

An earlier and much shorter version of chapter I appeared as "'Like Nowhere Else': Imagining Provincetown for the Lesbian and Gay Family," in Tourism Imaginaries at the Disciplinary Crossroads: Place, Practice, Media, edited by Maria Gravari-Barbas and Nelson Graburn, 180-194 (Farnham: Ashgate, 2016). Reprinted with permission.

A shorter version of chapter 2 was published as "Cruising to Equality: Tourism, U.S.

Homonationalism, and the Lesbian and Gay Family Market," WSQ: At Sea 45, no. I/2 (2017). Reprinted with permission.

Copyright $\odot 2018$ by Liz Montegary

All rights reserved

No part of this book may be reproduced or utilized in any form or by any means, electronic or mechanical, or by any information storage and retrieval system, without written permission from the publisher. Please contact Rutgers University Press, io 6 Somerset Street, New Brunswick, NJ 0890 . The only exception to this prohibition is "fair use" as defined by U.S. copyright law.

(क)

The paper used in this publication meets the requirements of the American National Standard for Information Sciences-Permanence of Paper for Printed Library Materials, ANSI Z39.48-1992.

www.rutgersuniversitypress.org

Manufactured in the United States of America 
For Nanny Scoop 
